\title{
Literature and Project-Based Learning and Learning Outcomes of Young Children
}

\author{
Veena Prachagool ${ }^{1}$ \\ ${ }^{1}$ Faculty of Education, Mahasarakham University, Thailand \\ Correspondence: Veena Prachagool, Faculty of Education, Mahasarakham University, Thailand.
}

Received: September 3, 2021

Accepted: October 4, 2021

Online Published: November 26, 2021

doi:10.5539/ies.v14n12p93

URL: https://doi.org/10.5539/ies.v14n12p93

\begin{abstract}
In the early years, children learn by taking an action and touching opportunities which experiences the world as much as possible. It is an internal process that allows children to meaningfully reflect their experiences from abstract to further learning. Literature and project-based learning management is a learning approach that strengthens the attitude of the pursuit of knowledge, helping children to have a habit of reading, creating opportunities to leading in the discovery of something meaningful to life. The research objectives were to study learning outcomes of young children through literature and project-based learning. Twenty-five young children were studied and reported their learning outcomes. Data were collected through variety of methods: observation, debriefing focus group, and interviews after the scenario. Data were collected by qualitative and quantitative methods. The findings indicated that young children had the highest level of understanding and ability to manage literary learning and projects. They also had ability to provide the most literary and project management environment were ranges low and highest based on the different perception and potential of learning. It can be recommended literature and project-based learning is suitable for early childhood education.
\end{abstract}

Keywords: early childhood, learning management, literature, project-based learning

\section{Introduction}

Early years learning is critical period of life, they can gain knowledge and understanding about natural world. Nature of learning lead the way of curiosity based on developmental achievement, presenting more interesting things about it, and when the child presents his or her ideas (Stirrup et al., 2017a, 2017b; MacBlain, 2018; Sims, 2020). They will learn about decision making, vote, and respect the democracy. Individual different, needs, interesting, and different potential of learning as much as you can be promoted by diversity of learning experiences. Learning in appropriate way help them to continue about natural and physical science and then can employ science communication to other people (Darling-Hammond et al., 2020).

The science of early childhood education is based on the concept of organizing a learning experience by committing learning in doing. Education is a process of living and a preparation for future living, it is necessary for all to live with meaningful learning. This focus on learning management that allows students to experience life while studying so that they can develop skills that are consistent of thinking development. Teachers are supporting and promoting processes along the learning path (Darling-Hammond, 2020). The theory that is used as the foundation for the creation of knowledge of learners at the heart of literary learning management and projects is emerged from constructivist theory (Maureen et al., 2018; Xu, 2019).

Vygotsky's cognitive development theory, children learn to develop intelligence and attitudes when interacting and collaborating with others, such as adults, teachers, and friends. Child faces challenging problems but cannot think of a solution alone because learning environment makes them think and learn through different solution (Kim et al., 2019). When parents and other people help and guide from working based on more experienced, the child will be able to solve that problem and learn. Helping children solve problems on their own by providing clues, reminders, encouragement, breaking the problem down into steps, providing examples, or other things that will help children solve problems and learn on their own (Alzahrani et al., 2019; Londoño et al., 2019).

Piaget's cognitive development theory of children is learned from two large processes within the child. They organize intellectual structure and learning adaptation. Children will try to understand experiences by using old ideas or old experiences with the absorption process. Children will change their minds about things, spoil them 
with a process of modification, until they can blend that new idea into harmony with old ideas. Such conditions contribute to equilibration, a process in which changes and causes this balanced state. This leads to intellectual development from one stage to the next for solving problems (Agarkar, 2019). The learning activities provided children be responsible, be open-minded, accept the opinions of others (Dzainudin et al., 2018). It also enhances the results of early childhood cognitive development assessments to a higher level. Preschoolers have to the understanding and ability to manage literary learning and projects as a base in all aspects.

Literature and project-based learning (LPBL) is a method of teaching and learning to strengthen the attitude of knowledge through a deep learning process that helps children have a passion for reading (Cattaneo, 2017; Essa \& Burnham, 2019; Darling-Hammond et al., 2020). Learn that reading is fun and can lead to the discovery of many meaningful things, as literary teaching is the base for children to receive. Experiences about places, people, and things around children that children may not have the opportunity to gain from direct experience (Crouch et al., 2019). Project teaching and literature is the base for children to gain knowledge. Ideas and ideas from new aspects literary experiences help children expand their borders of knowledge and the power of imagination. Project teaching and literature is a good base, helping children to have thinking skills. It also helps children understand the world. Gaining new experiences, observe, search, find information that makes it possible to get reliable information and can use it for further instruction.

Literature is an aesthetic learning activity which helping our children engage with reading, writing, creating, and amusing. The most study pay attention to symbols, wording, and communicating in literacy (Theodotou, 2017). Literature is made a connection to project-based learning that aims to strengthen good attitudes towards the pursuit of knowledge. It gives children an experience of places, people and things around them. The teaching method allows integration between teaching and literature are the base for children to gain knowledge. Literary experience allows children to expand their borders of knowledge and the power of imagination, helping them gain thinking skills, the use of language communication and the proper pursuit of knowledge. By focusing on learning that allows children to gain real experience while studying, they develop skills, starting with the student's interest in knowing as a particular subject together and then trying to understanding.

As a result of research related to project-based learning experiences and the management of literary learning experiences. Project-based learning and literatures can enhance learning experiences; children have developed basic scientific processes as thinking trainers. There is an organized thinking process, thoughtfulness, creativity as well as learning environments. Children are happy to study because they learn what they are interested in. Meanwhile, literature is a learning style that strengthens physical development. The research objectives were to study learning outcomes of young children through literature and project-based learning. It will be useful for preschoolers to make guideline in balance for learning experiences organization in young children.

\section{Methodology}

This research employed mixed methods during academic year 2020 from one primary school in northeast of Thailand. Participants were 25 young children (ages 5-6 years). In this research, the researcher collected data by organizing 32 learning experience plans. Literature and project-based learning project was used as dependent variable. Data were collected through variety of methods: observation, debriefing focus group, and interviews after the scenario (Table 1).

Table 1. Debriefing focus group interviews

\begin{tabular}{ll}
\hline Desirable characteristics & Debriefing focus group interviews \\
\hline & 1. Before the event, do the children have any questions? \\
(If you have any questions, tell the children about your questions) \\
2. Do children plan before activities? \\
3. Can children follow what is planned? \\
4. When the activity is completed, do the children get an answer from the question? \\
5. Do children wonder about the consequences of this activity? \\
1. Can children complete this activity in time? \\
2. During the activity, does anyone help your friends or sneak in other than assignments? \\
3. Can children tell teachers why the results of what they do are caused by this? \\
4. What do children feel after this activity?
\end{tabular}

Researcher analyzed the data based on the quality of behavioral observations in simulated situations and 
debriefing focus group, interviews after the scenario. Three observers pay attention to monitor learning behaviors and seek the consistency of score. Research tool consistency index is approved by expert opinions. The statistics used to analyze the data are based on the basic statistics of the literary learning management score and the project. as the base of early childhood teachers, and the literary and project-based learning of early childhood. Descriptive statistics include average and standard deviation. Level of learning can be interpreted by average as in below.

$$
\begin{array}{cc}
14.02-16.00 & \text { Highest } \\
12.01-14.01 & \text { High } \\
10.00-12.00 & \text { Low }
\end{array}
$$

\begin{tabular}{|c|c|c|c|c|c|c|}
\hline \multirow{2}{*}{ Students } & \multicolumn{3}{|c|}{ Observants } & \multirow{2}{*}{$\sum x$} & \multirow{2}{*}{$\bar{X}$} & \multirow{2}{*}{ Level of learning } \\
\hline & 1st Observant & 2nd Observant & 3rd Observant & & & \\
\hline 1 & 11 & 10 & 11 & 32 & 10.67 & Low \\
\hline 2 & 14 & 15 & 15 & 44 & 14.67 & Highest \\
\hline 3 & 15 & 15 & 15 & 45 & 15 & Highest \\
\hline 4 & 15 & 14 & 15 & 44 & 14.67 & Highest \\
\hline 5 & 12 & 14 & 14 & 40 & 13.33 & Highest \\
\hline 6 & 14 & 13 & 14 & 41 & 13.67 & Highest \\
\hline 7 & 11 & 11 & 12 & 34 & 11.33 & Low \\
\hline 8 & 15 & 15 & 14 & 44 & 14.67 & Highest \\
\hline 9 & 10 & 10 & 10 & 30 & 10 & Low \\
\hline 10 & 14 & 15 & 14 & 43 & 14.33 & Highest \\
\hline 11 & 16 & 16 & 16 & 48 & 16 & Highest \\
\hline 12 & 14 & 14 & 14 & 42 & 14 & High \\
\hline 13 & 13 & 14 & 14 & 41 & 13.67 & High \\
\hline 14 & 13 & 12 & 12 & 37 & 12.33 & High \\
\hline 15 & 14 & 14 & 14 & 42 & 14 & High \\
\hline 16 & 15 & 15 & 15 & 45 & 15 & Highest \\
\hline 17 & 12 & 13 & 12 & 37 & 12.33 & High \\
\hline 18 & 11 & 10 & 11 & 32 & 10.67 & Low \\
\hline 19 & 16 & 16 & 16 & 48 & 16 & Highest \\
\hline 20 & 13 & 13 & 12 & 38 & 12.67 & High \\
\hline 21 & 11 & 12 & 12 & 35 & 11.67 & Low \\
\hline 22 & 14 & 14 & 13 & 41 & 13.67 & High \\
\hline 23 & 14 & 14 & 14 & 42 & 14 & High \\
\hline 24 & 13 & 13 & 12 & 38 & 12.67 & High \\
\hline 25 & 14 & 15 & 14 & 43 & 14.33 & Highest \\
\hline
\end{tabular}

\section{Result}

Literature and project-based learning organization are the base of early childhood teachers found that preschoolers showed their ability to provide the most literary and project-based learning as well. The observation children and their behavior in the simulation through learning organization can be shown in Table 2 .

Table 2. Literary learning scores and projects are the base of early childhood from observing behaviors

Literary and project learning scores are based on children's age by observing behaviors in the observant through conditioning simulations. The research integrated literary and project-based learning to enhance young children in their scores. Desirable characteristics were observed and recorded by 3 observers. The level of learning can be indicated that they were at fluctuating level, ranges between low and highest. In addition, the debriefing focus group interviews can be responded to quantitative data.

The curiosity, children had interests and discussing in the group by talking before starting the activity what equipment to do to help the rabbit. All the children share the opinion "Make a car" "Why don't you do an amphibious car?" "Make sailboats". When bringing a boat to experiment with floating, the children were interested in the results of the experiment by saying "float" "It's not floating, it's tilted" When putting rabbits on 
board, most children comment that they sink. But when the results didn't sink, Boy A said, "The boat is too big". When asked if he had planned before this activity, he said "no" All the children answered at the same time: "No." In the means, Boy B offered, "why don't we make a small boat?" The researchers went on to ask what it was like when we didn't plan the results. All the kids answered, "the boat is enormous".

Responsibility, every child can present what their group together makes teachers listen to. All children can complete this activity in time, and when asked if anyone is not helping their friends during the activity. They will be asked if they will be able to do so. Every child says let's do it for everyone. Most children can tell their teachers why their group's boat didn't sink. Children said "because the boat is larger than the basin when placed on the basin, it looks like it is floating above the water" "because the milk cartons used to make the boats are lightweight, even with many items coming together, they can keep the boat afloat".

\section{Discussion}

Learning that allows children to develop skills, starting with having an interest in a particular subject. Teachers observe the child's interests by participating in conversations about things from listening tales or stories. Each child paid their curiosity to having something that they are particularly interested in. Teachers use this opportunity to draw out their child's hallmarks to motivate them to learn, with the topic. They can learn based on the needs of most children in the classroom activities (Rao et al., 2019). They focused on self-knowledge through a variety of media and learning methods.

Teachers should provide a learning experience for children to discover their own learning by creating good or suitable learning as concurrent with nature of learning. Children want to know, such as "why does the daytime not have stars?" "why do we see a full moon some days, but some days we see a single crescent moon?" "where did the meteor go?" and a variety of ways to find answers, such as "go to an expert inquiry about stars" "go to the planetarium" "find out on the Internet" "go observe and experiment". These quotes indicated they have curiosity and responsible learning about natural world (Arnott \& Duncan, 2019; Campbell et al., 2021).

The literature and project-based learning is an integral nature of science and nature of learning which meet children's requirements. The LPBL offered is not only a teaching from the side of preschoolers, but teachers who trying to find answers on active learning through science learning activities. Experimenting with real things allows children to learn from direct experiences that are appropriate for their learning nature and cognitive development (Panasan \& Nuangchalerm, 2010; Gilkerson et al., 2017; Rintakorpi \& Reunamo, 2017). It is consistent with Dewey, who believes that learning by acting helps children to practice things on their own according to their interests, aptitude, and potential of learning.

They will inspire motivation to children, they will have fun continuing to search for knowledge or eager to learn natural phenomena. Focus on organizing activities in an integrated manner through play. It is also consistent with activities for children aged 3-6 years. Acting from first-time experience, knowledge, skills, morality, ethics, and physical development. They can promote mind-on and hands-on activities in children a sense of achievement, instilling the character of that thing into the child for the rest of their lives (Chen et al., 2017; McLachlan \& Arrow, 2017; Barrable, 2019). Providing early childhood science experiences by providing children with first-time experiences is consistent with the form of project-based learning experiences and literature.

Children think and act in naturally by their own perception in relation to the learning nature of early childhood with curiosity. If a person has learned consistently with maturity, they will learn easily and quickly, but if they have to learn anything while there is no maturity for that activity. They will learn with difficulty or may not be able to learn that at all. As mentioned earlier, it is shown that in the organization of project-based learning experiences and literature activities, teachers who are responsible for organizing learning experiences are very important to early childhood learning (Prachagool et al., 2016; Page, 2018; Joo et al., 2020). The development of literary learning and projects as a base for early childhood has resulted in early childhood learning as well as learning.

\section{Acknowledgements}

This research is financially supported by Mahasarakham University.

\section{References}

Agarkar, S. C. (2019). Influence of learning theories on science education. Resonance, 24(8), 847-859. https://doi.org/10.1007/s12045-019-0848-7

Alzahrani, M., Alharbi, M., \& Alodwani, A. (2019). The effect of social-emotional competence on children academic achievement and behavioral development. International Education Studies, 12(12), 141-149. 
https://doi.org/10.5539/ies.v12n12p141

Arnott, L., \& Duncan, P. (2019). Exploring the pedagogic culture of creative play in early childhood education. Journal of Early Childhood Research, 17(4), 309-328. https://doi.org/10.1177/1476718X19867370

Barrable, A. (2019). The case for nature connectedness as a distinct goal of early childhood education. International Journal of Early Childhood Environmental Education, 6(2), 59-70.

Campbell, C., Jobling, W., \& Howitt, C. (Eds.). (2021). Science in early childhood. Cambridge University Press. https://doi.org/10.1017/9781108868419

Cattaneo, K. H. (2017). Telling active learning pedagogies apart: From theory to practice. Journal of New Approaches in Educational Research (NAER Journal), 6(2), 144-152. https://doi.org/10.7821/naer.2017.7.237

Chen, J. J., Li, H., \& Wang, J. Y. (2017). Implementing the project approach: A case study of hybrid pedagogy in a Hong Kong kindergarten. Journal of Research in Childhood Education, 31(3), 324-341. https://doi.org/10.1080/02568543.2017.1309479

Crouch, E., Radcliff, E., Hung, P., \& Bennett, K. (2019). Challenges to school success and the role of adverse childhood experiences. Academic Pediatrics, 19(8), 899-907. https://doi.org/10.1016/j.acap.2019.08.006

Darling-Hammond, L. (2020). Accountability in teacher education. Action in Teacher Education, 42(1), 60-71. https://doi.org/10.1080/01626620.2019.1704464

Darling-Hammond, L., Flook, L., Cook-Harvey, C., Barron, B., \& Osher, D. (2020). Implications for educational practice of the science of learning and development. Applied Developmental Science, 24(2), 97-140. https://doi.org/10.1080/10888691.2018.1537791

Dzainudin, M., Yamat, H., \& Yunus, F. (2018). Emerging young children's thinking through social and cognitive development in the project approach. Creative Education, 9(14), 2137-2147. https://doi.org/10.4236/ce.2018.914155

Essa, E. L., \& Burnham, M. M. (2019). Introduction to early childhood education. Sage Publications.

Gilkerson, J., Richards, J. A., \& Topping, K. J. (2017). The impact of book reading in the early years on parent-child language interaction. Journal of Early Childhood Literacy, 17(1), 92-110. https://doi.org/10.1177/1468798415608907

Joo, Y. S., Magnuson, K., Duncan, G. J., Schindler, H. S., Yoshikawa, H., \& Ziol-Guest, K. M. (2020). What works in early childhood education programs?: A meta-analysis of preschool enhancement programs. Early Education and Development, 31(1), 1-26. https://doi.org/10.1080/10409289. 2019.1624146

Kim, S., Raza, M., \& Seidman, E. (2019). Improving 21st-century teaching skills: The key to effective 21st-century learners. Research in Comparative and International Education, 14(1), 99-117. https://doi.org/ $10.1177 / 1745499919829214$

Londoño, S. P. V., De Soria, A. B. M., \& Rivas, S. (2019). Early childhood development and education: Theoretical convergences and divergences. International Education Studies, 12(7), 1-9. https://doi.org/10.5539/ies.v12n7p1

MacBlain, S. (2018). Learning theories for early years practice. Sage.

Maureen, I. Y., van der Meij, H., \& de Jong, T. (2018). Supporting literacy and digital literacy development in early childhood education using storytelling activities. International Journal of Early Childhood, 50(3), 371-389. https://doi.org/10.1007/s13158-018-0230-z

McLachlan, C. J., \& Arrow, A. W. (Eds.). (2017). Literacy in the early years: Reflections on international research and practice. Springer Singapore. https://doi.org/10.1007/978-981-10-2075-9

Page, J. (2018). Characterising the principles of professional love in early childhood care and education. International Journal of Early Years Education, 26(2), 125-141. https://doi.org/10.1080/09669760.2018.1459508

Panasan, M., \& Nuangchalerm, P. (2010). Learning outcomes of project-based and inquiry-based learning activities. The Social Sciences, 6(2), 252-255. https://doi.org/10.3844/jssp.2010.252.255

Prachagool, V., Nuangchalerm, P., Subramaniam, G., \& Dostal, J. (2016). Pedagogical decision making through the lens of teacher preparation program. Journal for the Education of Gifted Young Scientists, 4(1), 41-52. https://doi.org/10.17478/JEGYS.2016116351 
Rao, N., Richards, B., Sun, J., Weber, A., \& Sincovich, A. (2019). Early childhood education and child development in four countries in East Asia and the Pacific. Early Childhood Research Quarterly, 47, 169-181. https://doi.org/10.1016/j.ecresq.2018.08.011

Rintakorpi, K., \& Reunamo, J. (2017). Pedagogical documentation and its relation to everyday activities in early years. Early Child Development and Care, 187(11), 1611-1622. https://doi.org/10.1080/03004430.2016.1178637

Sims, M. (2020). The importance of early years education. In Teaching early years (pp. 20-32). Routledge. https://doi.org/10.4324/9781003117704-3

Stirrup, J., Evans, J., \& Davies, B. (2017a). Early years learning, play pedagogy and social class. British Journal of Sociology of Education, 38(6), 872-886. https://doi.org/10.1080/01425692.2016.1182010

Stirrup, J., Evans, J., \& Davies, B. (2017b). Learning one's place and position through play: Social class and educational opportunity in early years education. International Journal of Early Years Education, 25(4), 343-360. https://doi.org/10.1080/09669760.2017.1329712

Theodotou, E. (2017). Literacy as a social practice in the early years and the effects of the arts: A case study. International Journal of Early Years Education, 25(2), 143-155. https://doi.org/10.1080/09669760.2017.1291332

Xu, F. (2019). Towards a rational constructivist theory of cognitive development. Psychological Review, 126(6), 841. https://doi.org/10.1037/rev0000153

\section{Copyrights}

Copyright for this article is retained by the author(s), with first publication rights granted to the journal.

This is an open-access article distributed under the terms and conditions of the Creative Commons Attribution license (http://creativecommons.org/licenses/by/4.0/). 